\title{
Survey of Weed Flora Composition in Coffee (Coffea arabica L.) Growing Areas of East Ethiopia
}

\author{
Hika Bersisa $^{1, *}$, Adisu Wagari ${ }^{2}$, Taddese Ishetu ${ }^{3}$ \\ ${ }^{1}$ Bako Agricultural Research Center, Bako, P.O. Box 03, Bako, Ethiopia. \\ ${ }^{2}$ Mechara Agricultural Research Center, Mechara, P.O. Box 19, Mechara, Ethiopia. \\ ${ }^{3}$ Jimma Agricultural Research Center, EARI, Ethiopia.
}

How to cite this paper: Hika Bersisa, Adisu Wagari, Taddese Ishetu. (2021) Survey of Weed Flora Composition in Coffee (Coffea arabica L.) Growing Areas of East Ethiopia. International Journal of Food Science and Agriculture, 5(3), 421-429.

DOI: $10.26855 /$ ijfsa.2021.09.012

Received: June 25, 2021

Accepted: July 21, 2021

Published: August 10, 2021

*Corresponding author: Hika Bersisa, Bako Agricultural Research Center, Bako, P.O. Box 03, Bako, Ethiopia.

Email: hikbersisa@gmail.com

\begin{abstract}
Coffee is one of the most important cash crops and the first most traded produce in Ethiopia. Ethiopia's coffee is exclusive of the arabica type (Coffea arabica L.) which belongs to the genus Coffea and the family Rubiaceae. Arabica coffee ( $C$. arabica L.) is a poor competitor of weed competition, while weed infestation is a major production constraint. The survey was conducted to assess and rank weed species for further management study in respective areas. The survey was conducted at coffee growing areas of East Ethiopia namely east Hararghe (Bedeno district) and west Hararghe (Boke, Daro Labu, and Habro districts). The assessment was done using both weed counting and interviewing growers for important points related to weed. Quadrate with a size of $0.5 \times 0.5 \mathrm{~m}$ was used. The collected data was analyzed via quantitative measures like weed frequency, field uniformity, mean-field density, dominance, and relative abundance. Accordingly, a total of 46 different weed species including 31 annuals and 12 perennials which comprised 35 broadleaved weeds 7 types of grass and 1 sedge (Representing by $81.3 \%, 16.3 \%$, and $2.3 \%$ respectively, by habitat) were identified in East coffee-growing areas of Ethiopia. The highest frequency value (85.34\%) was recorded with Gallant soldier (Galinsoga parviflora), field uniformity was dominated with African coach grass (Digitaria abyssinica) (68.52\%), mean-field density was by Salvia tiliifolia Vahl $\left(3,184.94\right.$ plants $\left./ \mathrm{m}^{2}\right)$, dominance was by Salvia tiliifolia Vahl (17.33\%), while relative abundance was by Salvia Tiliifolia Vahl. The most abundant weed species were ranked and prioritized using relative abundance, because, it is the summation value of all quantitative measures of a single weed species. Accordingly, the top ten most abundant coffee weed species in East Ethiopia were Salvia Tiliifolia Vahl (31.96), Gallant soldier (21.67), Witch weed (20.24), African coach grass (17.57), Browntop millet (15.80), Blackjack (15.80), White wort (15.34), Nutgrass (12.55), Congress weed (11.53), Wandering jaw (10.83). Therefore, any coffee growers should be used sound and sustainable weed management practices including cultural, chemical, and integrated weed management approaches, and further weed management studies should be conducted.
\end{abstract}

\section{Keywords}

Coffea arabica L., Weed Species, Frequency, Relative Abundance

\section{Introduction}

Coffee is one of the most important cash crops and the first most traded produce in Ethiopia. Ethiopia's coffee is exclusive of the arabica type (Coffea arabica L.) which belongs to the genus Coffea and family Rubiaceae. The signific- 
ance of coffee in the Ethiopian economy is enormous in that it accounts for about $29 \%$ of the total export earnings of the nation, 4.7 million small-holders directly involved in producing coffee and about 25 million people directly or indirectly depend on the coffee sector for their livelihoods [1].

However, the production of Arabica coffee in Ethiopia is to a great extent limited by several factors. Among coffee diseases, such as coffee berry disease, coffee wilt disease, and Coffee leaf rust, Coffee insect pests, mainly Antestia, leaf miners and coffee berry borer, Perennial grasses and sedges cause severe crop losses [2]. Research experience has shown that weeds can be serious competitors [2, 3]. Perennial grasses, sedges, and annual weeds with their fast and vigorous growth can easily smother coffee, and result in extremely low yields and affect the quality of the crop [3].

Excluding environmental variables, yield loss in coffee is caused mainly by competition with weeds. Weed interference is a severe problem in coffee, especially in the early part of the growing years, due to slow early growth, narrow canopy, and wide row spacing. Weeds compete with the coffee plants for resources such as light, nutrients, space, and moisture that influence the morphology and phenology of the crop. Furthermore, high weed infestation increases the cost of cultivation, lowers the value of land, and reduces the returns of coffee growers. These factors vary across regions and influence the composition and number of predominant weeds of economic importance to coffee production [3]. The increased cost of production has been a principal item in coffee production caused by weed species dominant and prevalent in areas where they are common, otherwise where they were previously efficiently and effectively managed.

Information on the presence, composition, importance, and abundance of weed species is needed to formulate appropriate weed management strategies. The distribution and nature of the weeds in coffee-growing areas could be different due to the different agronomic practices employed and the altitudes across the main coffee-growing areas. Specific sound knowledge obtained on the nature and extent of infestation of weed flora in the coffee-growing areas through weed surveys is essential for planning of their control and an indication to formulate recommendations on the standard practices as well as appropriate herbicide doses under ideal management. However, detailed information on the presence, composition, importance, and abundance of weed species especially in main coffee growing areas in eastern Ethiopia is lacking. Therefore, the present study was undertaken to assess and rank the dominant weed species for effective weed management.

\section{Materials and Methods}

The activity was conducted in four different Hararghe coffee growing districts namely Daro Labu, Habro, Boke and Bedeno. Four potential PAs per district and 5 to 7 fields were selected and assessed. Zigzag sampling method was used during the survey. Quadrate with $50 \mathrm{~cm} \times 50 \mathrm{~cm}$ size was used with the forwarding throwing method. Four to five quadrates were taken depending on farm size. Each and every weed species were counted manually and recorded. A questionnaire was also used to collect information from every coffee farmer. Answer and question were made with coffee farmers on a developed questionnaire related to coffee weed species, a usual practice carried out to manage coffee weed, coffee cropping system, about already existed weed species, and newly emerged weed plants between respondents and investigators.

\section{Data Computation and Analyze}

Collected data were summarized according to the following quantitative measures as described by [4].

\section{Weed frequency (F)}

Weed frequency was determined as the percentage of the total number of fields surveyed in which a species occurred in at least one quadrate in the following formulae;

$$
\mathrm{Fk}=\frac{\sum_{\mathrm{iY} \mathrm{i}}^{\mathrm{n}} \cdots}{\mathrm{n}} \times 100
$$

Where; $\mathrm{Fk}=$ frequency value for species $\mathrm{k}$; $\mathrm{Yi}=$ presence (1) or absence (0) of species $k$ in the field $i$ and $n$ being the number of fields surveyed.

\section{Field uniformity (FU)}

The field uniformity was calculated as the percentage of the total number of quadrates sampled in which a species occurred, as below;

$$
\mathrm{FUk}=\frac{\sum_{\mathrm{i}}^{\mathrm{n}} \sum_{\mathrm{i}}^{5-10} \operatorname{lil}_{\mathrm{ij}}}{5-10(\mathrm{n})} \times 100
$$

Where; FUk = field uniformity value for species $\mathrm{k}$, Yij= presence (1) or absence (0) of species kin quadrate $\mathrm{j}$ in field $\mathrm{i}$ and $\mathrm{n}$ is the number of fields surveyed.

\section{Field density (D)}

The field density of each species in the field was calculated by summing the number of plants in all the 20 quadrates per site and dividing by their area. 


$$
\mathrm{Dki}=\frac{\sum_{\mathrm{i} \mathrm{Zi}}^{5-10}}{\mathrm{Ai}} \times 100
$$

Where; Dki = density (in numbers $\mathrm{m}^{2}$ ) value of species $\mathrm{k}$ in field $\mathrm{i}, \mathrm{Zi}$ = number of plants of a species in quadrate $\mathrm{j}$ and $\mathrm{Ai}$ being the area in $\mathrm{m}^{2}$ of 5 to 10 quadrates in field $\mathrm{i}$.

\section{Mean field density (MFD)}

This value was obtained by totaling each field density (D) and dividing by the total number of fields. MFD is the mean number of plants per $\mathrm{m}^{2}$ for each species averaged over all fields sampled and it was determined as below;

$$
\text { MFDk }=\frac{\sum_{\mathrm{i} D K \mathrm{i}}^{\mathrm{n}} \ldots}{\mathrm{n}}
$$

Where; MFDk= mean-field density of species $\mathrm{k}$, Dki = density (in numbers $\mathrm{m}^{-2}$ ) of species $\mathrm{k}$ in the field, $\mathrm{i}$ and $\mathrm{n}$ is the number of fields surveyed.

Dominance (D) is the measure of the mean-field density of species k (MFDk) expressed as a percentage of the total mean-field density of all weed species (MFDl) and was established as;

$\mathrm{D}=(\mathrm{MFDk}) / \Sigma \mathrm{MFDl}) \times 100$

Similarity Index (SI): Similarity index (Community index) is the similarity of weed communities among different locations.

SI $=($ Epg $) /($ Epg + Epa + Epb)x100 (4) where, SI= similarity index; Epg = number of weed species found in all locations; Epa = number of species only in location $\mathrm{a}$; Epb = number of species only in location $\mathrm{b}$.

\section{Relative abundance (RA)}

This value was used to rank the weed species in the survey and it was assumed that the frequency, field uniformity, and mean-field density measures were of equal importance in describing the relative importance of a weed species. This value has no units but the value for one species in comparison to another indicates the relative abundance of the species [5]. Relative abundance values quantify the predominance of a given weed species in an environment by calculating the frequency, field uniformity, and density of a particular weed species relative to all other species observed. This value is an index that is calculated using a combination of frequency, field uniformity, and field density for each species, as described by [4]. Relative abundance allows for comparison of the overall abundance of one weed species versus another. The relative frequency (RF), relative field uniformity (RFU), and relative mean-field density (RMFD) shall be calculated by dividing the given parameter by the sum of the values for that parameter for all species and multiplying by 100 as illustrated below.

The relative frequency for species $k(R F k)$ as;

Relative field uniformity for species k (RFUk) as;

$$
\mathrm{RFk}=\frac{\text { Frequency value of species }}{\text { Sum of frequency values for all species }} \times 100
$$

$$
\text { RFUk }=\frac{\text { Field uniformity value for species } \mathrm{K}}{\text { Sum of field uniformity values for all species }} \times 100
$$

\section{Relative mean-field density for species k (RFUk) as;}

$$
\text { RMFDk }=\frac{\text { Mean field density value for species } \mathrm{K}}{\text { Sum of mean field density values for all species }} \times 100
$$

The relative the abundance of species k (RAK) was calculated as the sum of relative frequency, relative field uniformity, and relative mean field density for that species as;

$\mathrm{RAk}=\mathrm{RFk}+\mathrm{RFUk}+\mathrm{RMFDk}$

\section{Results and Discussions}

\subsection{Weed species Taxonomy}

A total of 46 different weed species including 31 annuals and 12 perennials which comprised of 35 broad leaf weeds, 7 types of grass, and 1 sedge (Representing by 81.3\%, 16.3\%, and 2.3\% respectively, by habitat) were identified in Eastern coffee-growing areas of Ethiopia (Table 1). The annual species were greater in number than perennial species and overall annual broadleaved species were more prevalent than perennial broadleaved species, grasses, and sedges. The same result was obtained by [6] at KIAMBU country.

The weed species represented 21 families in the surveyed area where the Asteraceae family had the highest number of weed species (8), followed by Poaceae (7), Solanaceae (3), Papaveraceae (3), Amaranthaceae (2), Lamiaceae (2), Portulacaceae (2), Rubiaceae (2), Oxalidaceae (2) (Table 1). The rest of the 12 families were represented by one species each. Asteraceae, Poaceae, and Papaveraceae families accounted together for $48.8 \%$ of the species established. Family Amaranthaceae, Lamiaceae, Portulacaceae, Rubiaceae, and Oxalidaceae were records together about 23.3\% of the species established in surveyed areas. While $1 \%$ of weed species were established by the remaining families including 
Acanthaceae, Commelinaceae, Convolvulaceae, Cyperaceae, Euphorbiaceae, Fabaceae, Orobanchaceae, Plantaginaceae, Polygonaceae, Primulaceae, Tiliaceae, and Verbenaceae.

\subsection{Occurrence and distribution of Coffee weed species in East Ethiopia}

The occurrence of weed species varies from area to area. Among identified species $42 \%$ of them were found across surveyed areas, whereas $28 \%$ were found at one area coffee-growing followed by $21 \%$ which were found at three cropping areas and $9 \%$ of them were found at two coffee cultivated areas (Table 2). While, some weed species occurred at all agro-ecology (Boke low land, D/Labu, and Habro midland, and Bedeno high land). This indicates that weed pest species have wide adaptability over other plants/crop species. For example, among 46 weed pest species 18 of them occurred and grown well across 4 surveyed coffee growing districts. All coffee weed pest species including broad leaves, grasses, and sedges were recorded from all surveyed areas.

\subsection{Weed species frequency $(F)$}

Coffee weed pest species were recorded with different frequency values from place to place. Weed pest species frequency value in an average recorded range between $85.34 \%$ and $12.50 \%$ which recorded with Gallant soldier (Galinsoqa parviflora) and Spiney pigweed (Amaranthusspinosus), respectively (Table 3). The ten superior weed frequency across surveyed area an averagely were Gallant soldier (85.34\%), African coach grass (81.03\%), Tiliifolia (76.19\%), Wandering jew (73.48\%), Nutgrass (68.05\%), Chicken weed (66.67\%), Prostrate wild petunia (66.67\%) Blackjack (57.40\%) and Congress weed (57.19\%). Among the top ten weed species $40 \%$ and $60 \%$ were perennial and annuals, respectively, while $20 \%$ of them were grasses and the remaining $80 \%$ were broad leaves weed species. Perennials lives throughout the year (twelve months) with coffee plants on the coffee farm. Unless the perennial weeds are controlled timely and adequately they can affect coffee productivity and production from year to year. This means finally it results in yield loss, poor quality, low price, and genetic erosion of coffee crops. A similar finding reported by [7] and [8] was revealed that different frequencies of different weed species including broad leaves, grasses, and sedges. Most of the common weeds in all surveyed areas were found in annual nature followed by perennials. [9] suggested that seeds of annual weeds survive in unfavorable conditions and they have able to complete their life cycle from seed to seed in a season.

\subsection{Field uniformity (FU) of weed species in surveyed areas}

Among 43 identified weed species high value of field uniformity was observed with African coach grass (Digitaria abyssinica) (68.52\%), while the lowest was recorded with Spiney big weed (Amaranthus spinosus) (0.48\%). The top ten weed species with first-class field uniformity were African coach grass(68.52\%), Gallant soldier (49.72\%), Browntop millet (43.97\%), Wild lettuce (42.58\%), White wort (41.84\%), Salvia tiliifolia Vahl (32.95\%), Congress weed (24.78\%), Nutgrass (24.48), Black nightshade (24.25\%) and Wandering jew (23.93\%)(Table 3). Whereas, the remaining 33 species were recorded with field uniformity value ranging between 22.22\% (Chicken weed, Portulaca quadrifida L.) and $0.48 \%$ (Spiney big weed, Amaranthus spinosus). It varied from district to district and even from kebele to kebele. This dissimilar may occur due to edaphic (including soil $\mathrm{pH}$, soil moisture, etc) and biological (dominated by another weed species, seed dormancy, eaten by insects and micro-organisms and etc) factors [10]. A similar result was reported by [11] in a rice field.

\subsection{Mean Field Density (MFD) of weed species per surveyed areas}

Salvia tiliifolia Vahl weed species belongs to Lamiaceae was recorded with a high field density value (3,184.94 plants $/ \mathrm{m}^{2}$ ) among the identified weed species from surveyed areas, while Snowdenia was recorded with a low field density value (18.18 plants $/ \mathrm{m}^{2}$ ) (Table3). The ten superior species under different weed families recorded with field density were Salvia tiliifoliaVahl $(3,184.94)$, Gallant soldier $(1,184.20)$, Browntop millet $(1,139.69)$, Goat weed $(714.92)$, Blackjack (645.67), African coach grass (644.41), Chicken weed (638.10), Congress weed (379.31), Nutgrass (324.35) and Creeping wood sorrel (288.90 plants $/ \mathrm{m}^{2}$ ). This field density varied from district to district and even from kebele to kebele, farm to farm. Unlike field, density has resulted due to some factors like weed managements practiced by growers including cultural, mechanical, chemical and so on, biological including eaten by wild animals, birds, insects, over dominated by anther weed species and etc, physically like poor germination, soil pH, soil moisture stress and etc.

\subsection{Dominance (D) of Weed species in surveyed areas}

Across the surveyed areas the weed dominance ranged between $17.33 \%$ and $0.02 \%$ which was recorded by Salvia tiliifolia Vahl and Snowdenia polystachya, respectively. Following Salvia tiliifolia Vahl, the dominance values and in descending order the top ten weed species were Gallant soldier (6.72), Blackjack (6.13), Goat weed (4.99), African coach grass (4.37), Browntop millet (3.74), Common cocklebur (3.64), Mexican poppy (3.58), Mexican marigold (3.08), 
Purslane (2.85), and Nutgrass (2.78) (Table 3).

\subsection{Relative abundance (RA)}

Value for the relative abundance of all weed species was varied from 31.96 to 1.34 which recorded by Salvia Tiliifolia Vahl and Snowdenia, respectively (Table 3). In this Salvia Tiliifolia, Vahl was significantly outstanding among the forty-six weed species identified in the surveyed areas. It topped both as a broadleaf weed species as well as in the overall top eleven (11) weeds species that were established to have a relative abundance (RA) value $\geq 9.75 \%$. In descending order, Salvia tiliifolia Vahl was followed by Gallant soldier (21.67), Witch weed (20.24), African coach grass (17.57), Browntop millet (15.80), Blackjack (15.80), White wort (15.34), Nutgrass (12.55), Congress weed (11.53), Wandering jew (10.83), and Chicken weed (9.75\%). Among the ten most abundant species, seven of them are broad leave while 2 are grasses and remain one is a sedge.

Table 1. Coffee weed species taxonomy surveyed around Hararghe coffee-growing areas

\begin{tabular}{|c|c|c|c|c|}
\hline Family & Common name & Scientific name & Life Cycle & Morphology \\
\hline Acanthaceae & Prostrate wild petunia & Ruelliaprostrata Poir & $\mathrm{P}$ & Broadleaf \\
\hline \multirow[t]{2}{*}{ Amaranthaceae } & Slender amaranth & Amaranthusviridis Hook. F. & A & Broadleaf \\
\hline & Devil's horsewhip & Achyranthesaspera L. & $\mathrm{P}$ & Broadleaf \\
\hline \multirow[t]{8}{*}{ Asteraceae } & Wild lettuce & Lactucacapensis Thunb & A & Broadleaf \\
\hline & Goat weed & Ageratum conyzoides L. & A & Broadleaf \\
\hline & Gallant soldier & Galinsoqaparviflora & A & Broadleaf \\
\hline & Guizotia scabra & & A & Broadleaf \\
\hline & Congress weed & Partheniumhysterophorus $L$. & A & Broadleaf \\
\hline & Bristly star bur & Acanthospermumhispidum DC. & $\mathrm{P}$ & Broadleaf \\
\hline & False daisy & Eclipta alba L. & A & Broadleaf \\
\hline & Black jack & BidenspilosaL. & A & Broadleaf \\
\hline Commelinaceae & Wandering jaw & Commelinabenghalensis L. & $\mathrm{P}$ & Broadleaf \\
\hline Convolvulaceae & Ivy leaf morning glory & Ipomoea hederacea (L.) Jacq & A & Broadleaf \\
\hline Cyperaceae & Nutgrass & CyperusrotundusL. & $\mathrm{P}$ & Sedge \\
\hline Euphorbiaceae & Wild poinsettia & Euphorbia geniculataOrteg. & A & Broadleaf \\
\hline Fabaceae & Heart leaf indig & IndigoferacordifoliaHeyne. ex Roth. & A & Broadleaf \\
\hline \multirow[t]{2}{*}{ Lamiaceae } & White wort & Leucasmartinicensis R. Br. & A & Broadleaf \\
\hline & Tiliifolia & Salvia tiliifolia Vahl & A & Broad leaf \\
\hline Orobanchaceae & Witch weed & Strigaasiatica L. & A & Broadleaf \\
\hline \multirow[t]{2}{*}{ Oxalidaceae } & Creeping wood & Oxalis corniculata L. & $\mathrm{P}$ & Broadleaf \\
\hline & Clover & Trifoliumrueppellianum & A & Broadleaf \\
\hline \multirow[t]{3}{*}{ Papavaraceae } & Mexican poppy & Argemonemexicana L. & A & Broadleaf \\
\hline & Mexican marigold & Tagetesminuta L & A & Broad leaf \\
\hline & Pimpefnil & Anaqallisarvensis & A & Broadleaf \\
\hline Plantaginaceae & Buckhorn Plantain & Plantagolanceolata & A & Broadleaf \\
\hline \multirow[t]{7}{*}{ Poaceae } & Brown top millet & Brachiariaramosa (L.) Stapf & A & Grass \\
\hline & African coach grass & Digitariaabyssinica & $\mathrm{P}$ & Grass \\
\hline & Crowfoot grass & Dactylocteniumaegyptium L. & A & Grass \\
\hline & Bermuda grass & Cynodondactylon (L.) Pers. & $\mathrm{P}$ & Grass \\
\hline & Half grass. & DesmostachyabipinnataStapf & $\mathrm{P}$ & Grass \\
\hline & Love grass & Setariaverticillata & A & Grass \\
\hline & Star grass & Cynodondactylon (L.) Pers. & $\mathrm{P}$ & Grass \\
\hline Polygonaceae & Double thorn & Oxygonumsinuatum & A & Broad leaf \\
\hline \multirow[t]{2}{*}{ Portulacaceae } & Purslane & Portulacaoleracea L. & A & Broadleaf \\
\hline & Chicken weed & PortulacaquadrifidaL. & A & Broadleaf \\
\hline Primulaceae & Scarlet pimpernel & Anagallisarvensis L. & A & Broadleaf \\
\hline \multirow[t]{2}{*}{ Rubiaceae } & Sticky willy & Galiumaparine L. & A & Broadleaf \\
\hline & Snowdenia & Snowdeniapolystachya & A & Broadleaf \\
\hline \multirow[t]{3}{*}{ Solanaceae } & Black nightshade & Solanumnigrum L. & A & Broadleaf \\
\hline & Thorn apple & Daturametel L. & A & Broad leaf \\
\hline & Chinese lantern & Nicandraphysalodes & A & Broadleaf \\
\hline Tiliaceae & Burbush & TriumfettarhomboideaJacq. & $\mathrm{P}$ & Broadleaf \\
\hline Verbenaceae & Wild sage & Lantana camera L. & $\mathrm{P}$ & Broadleaf \\
\hline
\end{tabular}


Table 2. Weed species with their family observed and recorded in a coffee farm in Hararghe districts

Weeds Species

Prostrate wild petunia

Slender amaranth

Devil's horsewhip

Wild lettuce

Goat weed

Gallant soldier

Guizotia scabra

Congress weed

False daisy

Blackjack

Wandering jaw

Ivy leaf morning glory

Nutgrass

Wild poinsettia

White wort

Witch weed

Creeping wood sorrel

Clover

Mexican poppy

Mexican marigold

Pimpefnil

Buckhorn Plantain

Browntop millet

African coach grass

Crowfoot grass

Bermuda grass

Love grass

Star grass

Double thorn

Purslane

Chicken weed

Scarlet pimpernel

Sticky willy

Snowdenia

Black nightshade

Thorn apple

Chinese lantern

Burbush

Wild sage
Bristly star bur

Heartleaf indig

Salvia TiliifoliaVahl

Half grass.

Bedeno

Boke

$\mathrm{D} / \mathrm{Labu}$

Habro
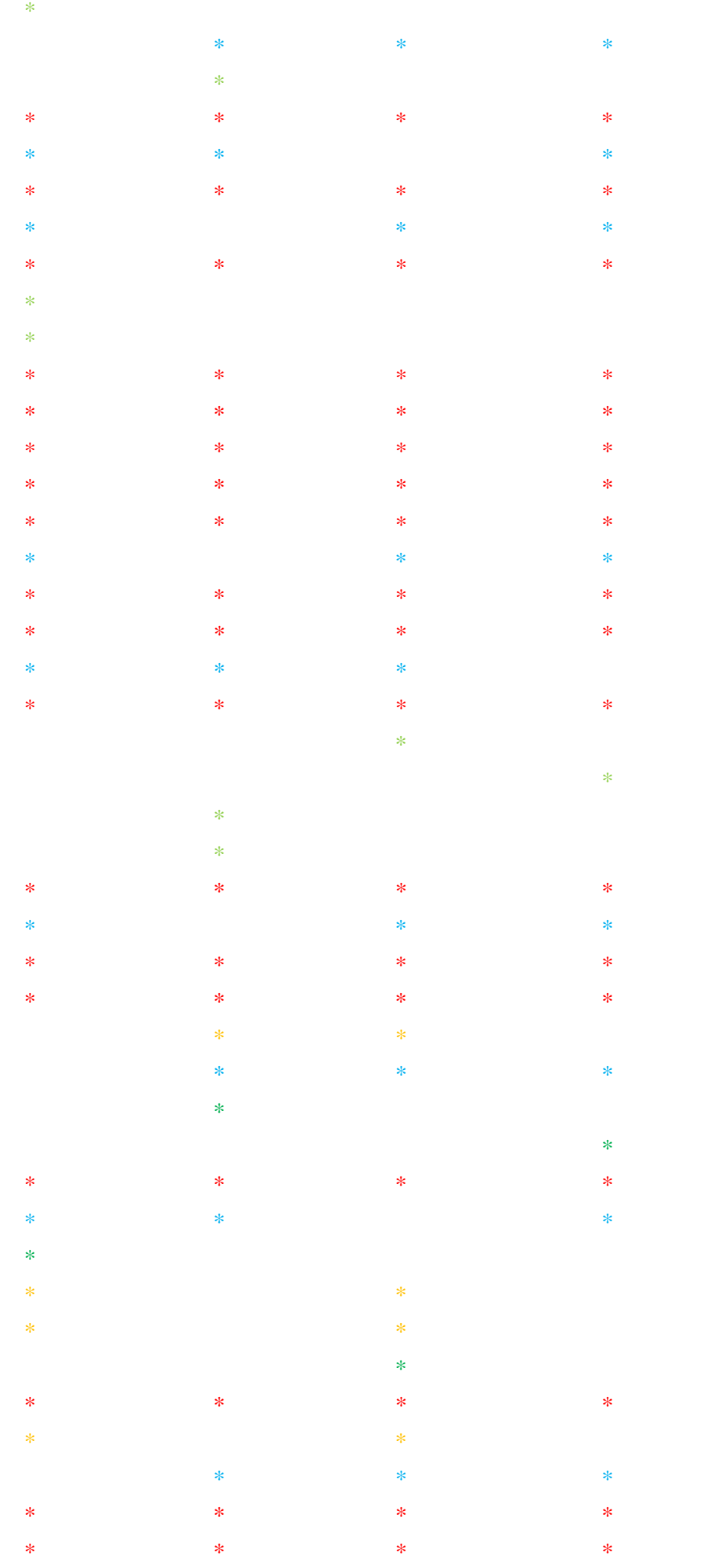

Note: * Occurrence of weed species at one area * at two areas *at three areas * at four areas 
Table 3. Quantitative measures of coffee weed species across surveyed areas of East Ethiopia during 2018

\begin{tabular}{|c|c|c|c|c|c|c|}
\hline S/No & Weed Species & $\mathrm{F} \%$ & FU\% & MFD, plant $/ \mathrm{m}^{2}$ & $\mathrm{D} \%$ & RA \\
\hline 1 & African coach grass & 81.03 & 68.52 & 644.41 & 264.65 & 17.57 \\
\hline 2 & Asthma herb & 45.00 & 4.69 & 110.48 & 53.39 & 6.44 \\
\hline 3 & Bermuda grass & 37.90 & 7.46 & 118.18 & 54.51 & 6.58 \\
\hline 4 & Blackjack & 57.40 & 8.99 & 645.67 & 237.36 & 15.80 \\
\hline 5 & Black nightshade & 46.02 & 24.25 & 36.63 & 35.63 & 6.99 \\
\hline 6 & Bristly starbur & 33.33 & 3.70 & 19.05 & 18.69 & 2.73 \\
\hline 7 & Browntop millet & 50.80 & 43.97 & 1139.69 & 411.49 & 15.80 \\
\hline 8 & Buckhorn Plantain & 24.21 & 1.98 & 43.00 & 23.06 & 6.80 \\
\hline 9 & Burbush & 41.89 & 11.60 & 101.11 & 51.53 & 5.38 \\
\hline 10 & Chicken weed & 66.67 & 22.22 & 638.10 & 242.33 & 9.75 \\
\hline 11 & Chinese lantern & 25.99 & 2.38 & 53.51 & 27.29 & 3.69 \\
\hline 12 & Common cocklebur & 25.00 & 1.67 & 152.38 & 59.68 & 5.67 \\
\hline 13 & Congress weed & 57.19 & 24.78 & 379.31 & 153.76 & 11.53 \\
\hline 14 & Creeping wood sorrel & 35.00 & 5.79 & 288.90 & 109.90 & 4.80 \\
\hline 15 & Crowfoot grass & 56.11 & 15.88 & 71.99 & 47.99 & 8.12 \\
\hline 16 & Double thorn & 31.39 & 9.86 & 23.23 & 21.49 & 4.10 \\
\hline 17 & False daisy & 26.49 & 3.70 & 19.05 & 16.41 & 1.95 \\
\hline 18 & Gallant soldier & 85.34 & 49.74 & 1184.20 & 439.76 & 21.67 \\
\hline 19 & Goat weed & 32.72 & 13.74 & 714.92 & 253.79 & 9.34 \\
\hline 20 & Guizotia scabra & 25.33 & 2.21 & 126.88 & 51.47 & 4.90 \\
\hline 21 & Half grass & 27.18 & 8.89 & 18.76 & 18.28 & 3.77 \\
\hline 22 & Heartleaf indig & 31.05 & 9.21 & 101.30 & 47.19 & 4.27 \\
\hline 23 & Humera weed & 33.33 & 20.00 & 57.14 & 36.83 & 7.07 \\
\hline 24 & Ivy leaf morning glory & 30.93 & 6.76 & 68.66 & 35.45 & 3.92 \\
\hline 25 & Love grass & 23.81 & 2.56 & 114.29 & 46.89 & 4.85 \\
\hline 26 & Meskel flower & 12.50 & 3.89 & 168.61 & 61.67 & 5.09 \\
\hline 27 & Mexican marigold & 33.88 & 11.64 & 236.77 & 94.10 & 7.83 \\
\hline 28 & Mexican poppy & 33.33 & 6.67 & 152.38 & 64.13 & 6.83 \\
\hline 29 & Nutgrass & 68.05 & 24.48 & 324.35 & 138.96 & 12.55 \\
\hline 30 & polygonumaviculma & 38.39 & 11.96 & 142.42 & 64.26 & 5.00 \\
\hline 31 & Prostrate wild petunia & 66.67 & 15.58 & 114.29 & 65.51 & 6.45 \\
\hline 32 & Purslane & 26.19 & 8.46 & 258.20 & 97.62 & 5.93 \\
\hline 33 & Salvia tiliifoliaVahl & 76.19 & 32.95 & 3184.94 & 1098.03 & 3.15 \\
\hline 34 & Scarlet pimpernel & 25.00 & 8.33 & 76.19 & 36.51 & 5.64 \\
\hline 35 & Slender amaranth & 40.36 & 10.19 & 39.59 & 30.04 & 1.34 \\
\hline 36 & Snowdenia & 12.50 & 0.48 & 18.18 & 10.39 & 3.93 \\
\hline 37 & Spiney pigweed & 12.50 & 0.48 & 141.82 & 51.60 & 2.01 \\
\hline 38 & Sticky willy & 25.00 & 2.08 & 38.10 & 21.73 & 1.73 \\
\hline 39 & Thorn apple & 19.64 & 1.37 & 18.61 & 13.21 & 31.96 \\
\hline 40 & Wandering jaw & 73.48 & 23.93 & 159.09 & 85.50 & 10.83 \\
\hline 41 & White jute & 14.29 & 0.65 & 38.10 & 17.68 & 2.01 \\
\hline 42 & White wort & 72.23 & 41.84 & 198.02 & 104.03 & 15.34 \\
\hline 43 & Wild lettuce & 38.49 & 42.58 & 44.99 & 42.02 & 7.13 \\
\hline 44 & Wild poinsettia & 30.73 & 8.13 & 145.60 & 61.49 & 5.10 \\
\hline 45 & Wild sage & 39.24 & 10.01 & 141.45 & 63.56 & 5.09 \\
\hline 46 & Witch weed & 49.55 & 14.26 & 112.12 & 58.65 & 20.24 \\
\hline
\end{tabular}

\subsection{Similarity index (SI, in \%)}

According to [8] described weed communities having similarity indices less than $60 \%$ among locations and seasons should be considered markedly different and distinct. Accordingly, in all surveyed districts weed species composition in Arabica coffee fields were showed a dissimilarity index (SI $<60 \%$ ) (Table 4). This is very an essential in that even at different PAs of coffee farms found in the the same district which is at the same crop age; the weed composition is very different. The difference in altitude, macro, and microclimate, soil textures and farmers practices of weed/field man- 
agement applied to the different survey districts/PAs could be affected the distribution, abundance, and dominance of the weed species [12]. An earlier study of [13] revealed that weed growth, density and distribution was varying from site to site depends on soil and climatic factors that affect the weed flora, and field management practices took by growers.

\subsection{Interaction of important factors and both weed composition and field density under coffee fields}

\subsubsection{Impact of coffee age on emergence and growth of weed species}

The coffee age has played a great role in weed emergence and its composition. Different weed species compete with more coffee plants at the young stage rather than at the elder stage. Coffee plant become shade to weed and suppresses their emergence and growth when aged. As coffee becomes aged, its canopy also expanded at the same time and block sun radiation from the emerged weeds underneath it. Additionally, the shed/dropped coffee leaves cover the ground and prevent weed emergence.

Hence, young coffee should be given good weed management to secure high yield and quality. In the present study, the result revealed that high weed field density $\left(2,483.72\right.$ plants $\left./ \mathrm{m}^{2}\right)$ was recorded from young coffee than the aged one (Figure 1). Weed plants grow freely without any limitation in young coffee farms rather than in the oldest coffee farm unless coffee farms are well managed.

Table 4. Similarity index of weed community at different location of East Ethiopian coffee growing areas

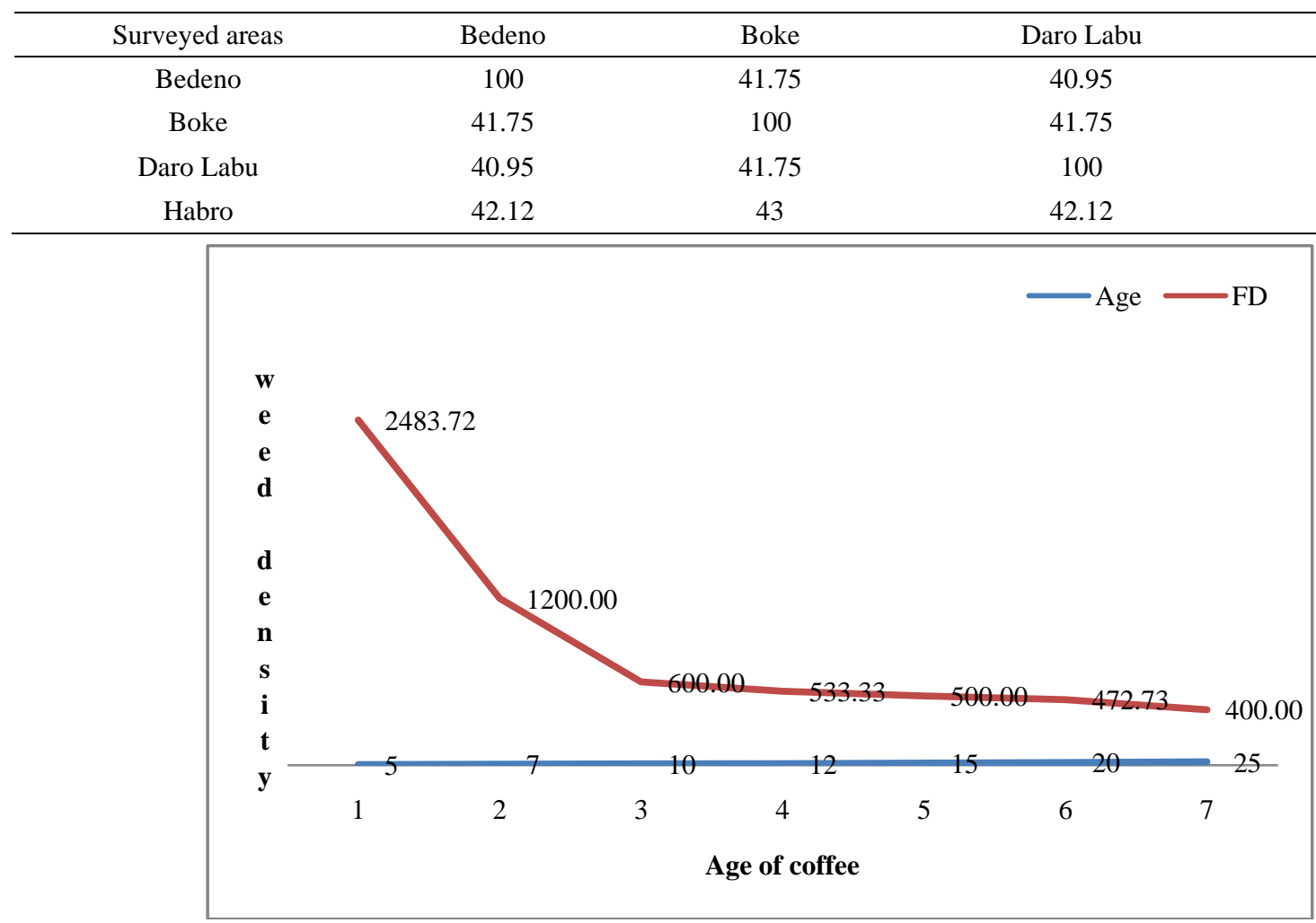

Figure 1. Impact of coffee age on emergence and growth of weed.

\subsubsection{Weed composition and field density in shaded and open sun coffee farm}

High (12 weed kinds) weed composition was recorded under open sun coffee farm, while low (5 weed kinds) weed composition was recorded under a shaded coffee farm. Similarly high field density was recorded from open sun coffee farm, whereas low field density was recorded from a shaded coffee farm. Under shaded coffee farm weed grow has restricted where the shade trees' canopy always block sun radiation penetration to the weed plants which finally leads to weed suppression. In the same way, leaves shed from the shade trees cover the ground and serve as mulching which results in blocking of weed seed emergence.

\subsubsection{Management practice versus weed composition}

Under surveyed areas coffee farmers were practicing some different agronomic management in order to manage weed species in their own coffee farms. However, some growers have managed their coffee farm as well while some of else not well. During the survey different weed field densities were recorded from the different coffee farms of study 
areas. Accordingly high (12 weed kinds) field density $\left(2,483.72\right.$ plants $\left./ \mathrm{m}^{2}\right)$ was recorded from coffee farm remain with weedy. Among weed management practiced by Hararghe coffee growers, hoeing followed by soil mulching has recorded with low weed field density.

\subsubsection{Effect of coffee intercropping with annual crops on weed composition}

As usual Hararghe farmers are practicing intercropping and alley cropping systems in order to win land shortage. Mainly they have been intercropped coffee with maize, sorghum, haricot bean, groundnut, barely and etc. Accordingly, significant weed density was recorded from different coffee farms intercropped with different crops. For example, low field density and the small number of weed species were recorded from coffee farms intercropped with legumes (groundnut and haricot bean) and barely crops which are cover the ground and compete on space. According to their morphological structure crops suppresses weed plants at different degree.

\section{Conclusion and Recommendation}

Weed species composition varied between and within the locations in zones at all surveyed areas. In the present study, a total of 46 coffee weed pest species belongs to 21 families were assessed and identified. Among 34 annuals and 12 perennials which comprised of 38 broadleaf weeds 7 types of grass and 1 sedge. During the survey, relatively abundant top ten identified weed species were Salvia Tiliifolia Vahl (31.96), Gallant soldier (21.67), Witch weed (20.24), African coach grass (17.57), Browntop millet (15.80), Blackjack (15.80), White wort (15.34), Nutgrass (12.55), Congress weed (11.53), Wandering jew (10.83). Thus, different weed management options would be required for the locations differing in weed flora composition, while all surveyed areas had shown the similarity indices less than sixty percent $(<60 \%)$. Further identification of weed species composition, characteristics, competition, and flora shift is necessary to adopt effective weed management options.

\section{Acknowledgments}

The authors extended their thanks to IQQO and EARI who support financially and facilitated this study. All technical staff of the coffee research case team is also appreciated for their support in data collection.

\section{References}

[1] CSA. (2015). Federal Republic of Ethiopia, Central Statistical Agency, Agricultural Sample Survey Report o(n Area and Production of Major Crops, 2014/2015, Vol. 1, Statistical Bulletin 578, May 2015, Addis Ababa, p. 121.

[2] DemelashTeferi. (2017). Coffee weed management review in South West Ethiopia. International Journal of Agriculture and Biosciences, 6(5): 252-257.

[3] Tadesse Eshetu and Tesfu Kebede. (2015). Effect of weed management methods on yield and physical quality of coffee at Gera, Jimma zone, South West Ethiopia. Journal of Resources Development and Management, 11: 82-89.

[4] Thomas, A. G. (1985). Weed survey system used in Saskatchewan for cereal and oilseed crops. Weed Science, 33: $34-43$.

[5] Thomas, A. G. and Wise, R. F. (1987). Weed survey of Saskatchewan for cereal and oilseed crops. Weed surveys series. Pub.87-1. Agri. Can. Regina, Saskatchewan. P. 251.

[6] G. G. Migwi, E. S. Ariga, and R. W. Michieka. (2017). A Survey on Weed Diversity in Coffee Estates with Prolonged Use of Glyphosate in Kiambu County, Kenya. International Journal of Scientific Research and Innovative Technology, 4(2): 82-94.

[7] Begum, M. (2006). Biology and management of Fimbristylismiliacea (L.) Vahl. Ph.D Thesis, University Putra Malaysia, Serdang Darul Ehsan, Malaysia.

[8] Begum, M. Juraimi, A. S Azmi, M., Syed Omar S. R., and Rajan A. (2008). Weed flora of different farm blocks in block-1 of Muda rice granary in peninsular Malaysia. J. Biosci., 19: 33-43.

[9] Singh, A., Sharma, G. P., and Raghubanshi, A. S. (2008). Dynamics of the functional groups in the weed flora of dry land and irrigated agro ecosystems in the Gangetic plains of India. Weed Biological. Manage, 8: 250-259.

[10] Hakim, M. A., A. S. Juraimi, M. R. Ismail, M. M. Hanafi, and A. Selamat. (2010). Distribution of weed population in the coastal rice growing area of Kehah in Peninsular Malaysia. Journal of Agronomy, 9: 9-16.

[11] Hakim, M. A., Juraimi, A. S., Razi Ismail, M. Hanafi, M., and Selamat, A. (2013). Survey on weed diversity in coastal rice fields of sebarangperak in peninsular Malaysia. Journal of Animal \& Plant Sciences, 23(2): 534-542.

[12] Mennan, H. and D. Isik. (2003). Invasive weed species in onion production systems during the last 25 years in Amasya, Turkey. Pak. J. Bot., 35(2): 155-160.

[13] Saavedra, L. Torres, G. Hernan, G. Dez, B., and Hidalgo, B. (1990). Influence of environmental factors on weed flora of field crops. Quiver Valley. 